\title{
Authenticity and Commodification of Culture at Puri Anyar Kerambitan as Royal Tourism Attraction in Tabanan Regency, Bali Province, Indonesia
}

\author{
Hery Sigit Cahyadi \\ Bandung Institute of Tourism, Indonesia \\ E-mail: herysigit@gmail.com
}

Received: June 9, 2015 Accepted: July 8, 2015 Published: July 9, 2015

doi:10.5296/jsss.v3i1.7785 URL: http://dx.doi.org/10.5296/jsss.v3i1.7785

\begin{abstract}
Authenticity and commodification of culture still being a major issue in cultural tourism development. Some people consider that the changing of culture become tourist attractions will cause the loss of culture's authenticity through modification. Many scholars say that cultures that are performed as tourist attraction will lost its originality to adjust the tourist demand. Puri Anyar Kerambitan as a cultural tourism destination is viewed one of the cultural tourism destination which is considered by many experts and scholars that are modify their culture to fulfill the tourist's desire. In fact, The Puri is never change the originality and authenticity of its cultures they have. They may be modify their cultures to performed as a tourist attraction but in the other side they still preserve the original one. They created the other version of the cultures or created a new one to showed to the tourists. What Puri Anyar Kerambitan can be a model to other puri/palace how to maintain their culture authenticity without sacrifice their original cultures.

This research used a qualitative data analysis where interview was conducted to find out the perception of the respondent related to the authenticity and commodification of culture at Puri Anyar Kerambitan as a royal tourism destination in Bali, Indonesia.

The aim of this research are to find out how Puri Anyar Kerambitan as a royal tourism destination stay keep their culture authenticity and what kind of modification that a palace can do without sacrifice their culture authenticity.
\end{abstract}

Keywords: Authenticity, Commodification, Royal tourism 


\section{Introduction}

Much of the contemporary literature on the nature of modern tourism and its impact upon host societies relies on several important assumptions. In a most general way, these assumptions can be formulated as follows: First, tourism' is said to lead to "commoditization" (Greenwood, 1977) of areas in the life of a community which prior to its penetration by tourism have been within the domain of economic relations regulated by criteria of market exchange (cf. Appadurai, 1986). Local culture generally serves as the principal example of such commoditization. In particular, "colorful" local costumes and customs, rituals and feasts, and folk and ethnic arts become touristic services or commodities, as they come to be performed or produced for touristic consumption.

The concept of authenticity has played a prominent role in understanding tourist motivation and experience, and diverse debates and analyses have generated a plethora of literature in this field (Cohen, 1988a; Crang, 1996). The center of the debate lies in the meaning of authenticity. MacCannell proposed that "touristic consciousness is motivated by its desire for authentic experience"' (1976:101). Modern society is inauthentic and alienating, driving people to travel in search of the authentic since "reality and authenticity are thought to be elsewhere" (1976:3). But the touristic quest is doomed to failure, he argues, for all there is out there is a staged authenticity (Goffman, 1963), an inevitable consequence of the commodification process. A commodity-driven industry underlaid with market capitalism produces a false touristic consciousness and is the epitome of modernity. Post-modernity arrives when true (authentic) meanings of cultural products

and human relations are distorted by the constant reproduction process of signs and images. In this image-driven consumer society, the distinction between original and copy collapses, leaving only hyperrealities and simulacra (Baudrillard, 1983).

Over the last decade, authenticity in the sense of "original" or "real" has been increasingly refuted by social constructivists, who see reality as being socially constructed through negotiated meaningmaking and agreement (Bruner, 1994; Hughes, 1995). From this perspective, authenticity is subject to cultural selectivity (Halewood \& Hannam, 2001) and/or interpretation and the hegemonic voices of cultural marketers, scholars, local authorities, and more (Fawcett \& Cormack, 2001).

According to MacCannell (1973:593), the tourist, in his desire for authentic experience, is the modern embodiment of the religious pilgrim. Tourism thus appears to become a modern surrogate for religion (MacCannell 1973:589; cf. also Cohen In Press b.). However, it is implicit in MacCannell's analysis that there is no salvation in tourism: the tourist establishment dominates the tourist industry, and by mis- leading tourists to accept contrived attractions as "authentic," creates a "false touristic consciousness." A fully developed mass tourist system surrounds the tourist with a staged tourist space, from which there is "no exit." In many destinations, tourism requires the commoditization of culture in order to supply a relevant product for tourist consumption in the competitive marketplace (Girard, 2008; Govers \& Go, 2004). Planned tourism development, as opposed to tourism that evolves organically in a destination, is likely to have even more calculated impacts on cultural 
identity by intentionally controlling or manufacturing cultural elements to market to tourists (Greenwood, 1989).

Royal palace as a form of cultural tourism has a dilemmatic problem related to the authenticity as result of commodification. Some peoples especially experts and scholars view the commodification damage the authentic culture and it changes the cultures that has been maintain for centuries.

Puri Anyar Kerambitan as a royal tourism destination in Tabanan Regency, Bali, Indonesia often viewed as Puri that commercialized its cultures for tourism and make them lost their authenticity. On the other side, the tourists who came to this place considered the cultures they saw are authentic. The two different perception related to authenticity is an interesting thing to find out.

The purpose of the research is to find out how Puri Anyar Kerambitan as a royal tourism destination stay keep their culture authenticity and what kind of modification that a palace can do without sacrifice their culture authenticity.

\section{Method}

This research used a qualitative data analysis to describe the phenomenon of cultural tourism attraction at Puri Anyar Kerambitan and to find out the perception of the authenticity of the cultural tourism attraction in the palace, interview is conducted to some stakeholders who involved in cultural tourism at Puri Anyar Kerambitan. The stakeholders consist of 5 tour operator, 5 experts/scholars, the king of Puri Anyar Kerambitan, and 250 tourists.

\section{Literature Review}

\subsection{Authenticity}

The notion of authenticity is much debated in the tourism literature, including the related question of whether or not contemporary question of whether or not contemporary tourist actually seek out authentic experiences, or can even recognize them. Redfoot (1984) noted that some scholars is Believe the modern tourist generally uninterested in the authentic, while others have suggested that tourist are engage in a quest for the authentic. These views have a broad appeal and have meant that criticisms of tourism sound remarkably similar whether they come from the right or left of the political spectrum. Boorstin (1964) and MacCannel $(1973 ; 1976)$ reduce touristic experience to a 'pseudo' experience and lay blame on capitalism's ability to commoditize an experience into a cheap commodity available for sale to a mass market. Therefore, view touristic inauthenticity as a result of the general in authenticity of modern life.

The links between tourism and authenticity more generally have extensively explored by tourism researcher. Despite this work, there is still uncertainty about what is meant by authenticity. According to Trilling (1972) the word authenticity originated in the context of museums and refers to object that are what they claim to be. Ashworth and Tunbridge (1990:23) concur with the notion that authenticity derives from the object being conserved, and explain that an object may be deemed authentic because of its "intrinsic aesthetic or historic qualities". However, many would argue that the idea of the existence of a stringent and objective set of measures of 'authenticity' in unrealistic, and that therefore a more 
flexible concept must be adopted. Some commentators (Cohen, 1988; Sharpley, 1994) now regard authenticity as a socially constructed concept, whereby the criteria for the authentic are subjective and different for each individual visitor, and this is the position adopted in this present study.

The variability in people's views of authenticity allows the attitudes of different types of visitors to be investigated. Reisinger (1994:24) suggest that cultural tourists "want to encounter beauty, authenticity, uniqueness and novelty of the cultural product". However, it can be argued from the view point of the visitor that each individual perceives the cultural tourism product uniquely at the moment of consumption that is the attraction in interpreted differently by different visitors.

Asworth (1994:18) suggests, the "perceived problem of authenticity does not derive from any discrepancy between the interpreted heritage product and some historical truth...the discrepancy, and its resulting problem, lie in the different versions of authenticity as defined by different customers". Each individual visitor authenticates the resource for her or himself. This point to the fact that visitors may not be seeking the same kind of experience, even when they are visiting the same place.

\subsubsection{Conceptualization of Authenticity}

Authenticity is an extremely ambiguous concept, with people conceptualizing it in different and often conflicting ways. Therefore, it is essential to clarify the diverse ways in which authenticity may be linked to the tourist experience. The word "authentic" is frequently used in the tourism literature to assess the character of the tourist experience at tourism attraction and events, as well as the motivations of tourist. However, in general little sustained has been paid to explaining or defining this term precisely in relation to tourism. Part of the problem might be that the meaning of the term authenticity varies according to its diverse use. As Trilling states (1972:11) "the word authenticity comes so readily to the tongue these days and in so many connection that it may very well resist....efforts of definition". However, the relevant literature that conceptualizes authenticity can be placed into three broad but often overlapping categories. These are authentic as 'primitive', authentic as a 'social construct' of modern society, and authentic as a 'social construct' or 'negotiated construct'.

\subsubsection{Authentic as 'Primitive'}

Many researchers follow the line of analysis that 'authenticity' is a 'primitive' condition (MacCannel, 1973; 1976; Redfoot, 1984; Trilling, 1972). In its most simple form, Trilling asserts that the concept was originally used in the context of the museum to describe ancient objects which are "what they appear to be or are claimed to be" (1972:93), a usage which appears to remain the most widely accepted and understood, although it appears a little naïve. Following Trilling's (1972) origination of 'authentic' in the museum, curators and ethnographers have tended to view authenticity as a quality of pre-modern or pre-industrial life, and of cultural products produced before the influences of the modern west were experienced. Many authors also emphasis the related absence of commoditization in mass market relations as a crucial consideration in judgement of authenticity (Cornet; 1975). Cornet (1975:52) declared authentic as "any objects created for a traditional purpose and by a traditional artist", but if it "conforms to traditional forms". Cornet also argues that, in order to 
be acceptable as authentic, the product should not be manufactured "specifically for the market". Trilling (1972:127) argues "the machine....could make only inauthentic things, dead things. In tourism terms, Cohen (1988) argues that the modern tourist in a quest of authenticity looks for the pristine, the primitive and the natural. Above all, the modern tourist looks for that which remains unaffected by modernity, and hence can be viewed as primitive. Characteristic of a primitive or pre-modern society lie in the absence of industrialization, such as of mass production and of such technologies as mass communication through television, radio and more recently satellite communications. It is in these senses that the "primitive" is often ascribed as authentic.

\subsubsection{Authentic as a 'Social Construct' of the 'Modern' Society}

It follows that 'authenticity' can be regarded as an eminently modern value (Trilling 1972; Berger, 1973), whose emergence is closely related to the impact of modernity upon the unity of social existence. That is, an object is only authentic if it is created without the aid of modern materials, tools or machinery. This concept can be stretched to include not just physical objects but also society if it has lost its authenticity as it has been adapted, influenced, altered or contaminated by the modern, western world. Thus authenticity is often ascribed to a traditional culture, and it conveys a sense of the genuince, real or unique. Sharpley (1994) observes that in tourism the word authentic is frequently used to described products or works of art, cuisine, dress, language, festivals, rituals, architecture-in fact, everything that comprises a society's culture. Moreover, within tourism, it is also used to describe different types of travel, certain journeys or even entire holidays. Importantly, it is also frequently used to make the distinction between specialist or niche-market tourism products and mass tourism products, implying that mass tourism is somehow inauthentic. This can be linked to Cornet's (1975) description of the authentic which emphasizes the absence of modernity. The implication is that mass tourism is deliberately manufactured specifically for high volume mass market.

\subsubsection{Authentic as a "Social Construct" or "Negotiated Construct"}

Cohen (1988:383) expertly develops the discussion of authenticity when he suggest that it shoud be conceived as a negotiable, socially construct concept rather that a construct merely referring to objects produced using primitive, pre-modern techniques. He argues that mass tourism does not succeed because it is a colossal deception, but because most tourist entertain concepts of authenticity which are much looser that those entertained by intellectual and experts. Cohen (1988:383) declared that authenticity is thus a social construct that is negotiated, and renegotiated, by different individuals, types of tourists, and intellectuals and experts. Getz (1994:319) supports this argument when conceptualizing authenticity as 'a measure of the tourist's perceptions" and suggesting that what are one tourist may be satisfied with may cause another tourist dissatisfaction or disappointment. In other words, authenticity should be judged from the tourist's individual view point and will be unique to that tourist.

An interesting extention of this idea is offered by Selwyn (1996:21), who distinguishes between two distinct senses of the term 'authentic', namely 'hot authenticity' and 'cool authenticity'. 'Hot authenticity' refers to tourism which based on fiction and myths. This category is subdivided into more general authenticity of the mythical society, which Selwyn (1996:21) terms "myths of the authentic other and the authentically social", and the more 
specific authentic of the individual tourist within the mythical society, referred to as "myth of the authentic self'. According to Selwyn,'Myths of the authentic other and the authentically social' parallel the notion of the authentic as 'primitive', in that they are based on the tourist's search for a more perfect world, which is variously pre-modern and pre-commoditized. Selwyn (1996:23) describes this as "a world which is eminently and authentically social" and goes on to suggest that "what makes a tourist destination attractive is that it is thought to have a special characteristic... which derives from the sociability of its residents". Thus, the destination is authentically social because it resists the anti-social influences of external forces and has a general sense of a close-knit host community. The second form of 'hot authenticity', that is the myths of the authentic self', are based on the more specific sense of tourist gaining a personal perception that they have proximity to, and can identify with, the host community in the tourist attraction. The more the tourist can identify with members of the host community, including their desire to identify with the perceived tourist from the brochure, the greater the sense of authenticity. That is, the extent to which the individual tourist matches the type of tourist envisaged from the brochure. Selwyn (1996:24) argues that the construction of such scientifically-based investigation is subject to historical, economic and political forces which influence the knowledge offered to the tourist. In this way, cool authenticity is thus achieved if the information offered confirms the historical, economic and political beliefs of the tourist. It can be seen, therefore, that both hot authenticity and cool authenticity hold parallels with Cohen's (1988) negotiated social construct, and thus specific and unique to the individual.

\subsection{Commodification}

The logic of exchange, that central concept in marketing theory (Bagozzi, 1975), requires a recognition and understanding of two different concepts: a 'commodity', that article to be exchanged, and a 'consumer', that person who is able to engage in the exchange and acquisition of that commodity. If we were to take a walk through any town or city centre we could not fail to notice that commodities can potentially be manifest in potentially infinite varieties and forms. They can consist of any type of material or substance and, in the case of service commodities, may have no physical form at all.

Marketing theory has traditionally been primarily occupied with understanding the consumer rather than the commodities that form marketing exchanges (Belk, 1995b). The title 'consumer behaviour' which is applied to the vast majority of marketing courses that are directly concerned with consumption is but the most obvious illustration of this direction of interest. Consumer behaviour research has traditionally been accused of having an interest in consumption for the purpose of providing tools that allow commerce and business to manipulate and exploit the consumer (Alvesson, 1994).

Commodification describes that process by which potentially all aspects of everyday life can come to exist as commodities. This process is also referred to as 'commoditization' (Kopytoff, 1986; Hirschman, 1991) but also has a great deal in common with terms such as 'objectification', 'quantification' and 'industrialization' as well as arguments regarding the 'McDonaldization' (Ritzer, 1993) and 'Coca-Colonisation' of society (Cinquin, 1987).

The term 'commodification' is used here to describe a cultural and economic process that concerns the social relations between human beings and their material culture in 
contemporary capitalist society. Commodification is not only implicated in the economics of society but also involves an ideological and political dimension, all of which will be given consideration in this chapter. The prevalence of the commodity form is understood to have wide reaching effects on the cultural environment and cultural perception more generally, and does not simply concern the quantitative rise of consumer goods and services in modern society.

\section{Results and Discussion}

\subsection{Puri Anyar Kerambitan as Royal Tourism Destination}

Puri in Balinese language means palace and Puri Anyar Kerambitan is one of the eldest and the biggest kingdom in Bali that was established on $6^{\text {th }}$ century. In the $17^{\text {th }}$ century this kingdom was under the authorization of Dutch Colonial after loss in a war. After the independence of Indonesian Republic in 1945 this kingdom become a part of Indonesian Republic and loss their power as a kingdom. In 1960, the Indonesian government launched a rule about land reform that made the kingdom lost their land properties.

For centuries the kingdom lived from agricultures but after the land reform they also lost their income and food sources. That event made the king thought how to sustain the kingdom. In 1962 he had an idea to open the palace as a tourist destination to gain income for the palace and his family. Bali is known as a popular tourist destination since the colonialism for its cultures, beaches and landscapes and in the 60's Bali still visited by tourists. Base on that situation, the king started to create his palace as cultural tourism destination with three cultural product: royal dinner, royal dance and royal wedding. In order to avoid got negative perception from his families and peoples, he created and modified the cultures to performed to the tourists. He remove some original elements which related to rituals and religion because cultures and the rituals and religion are integrated part of Balinese life. What tourists enjoyed as cultural attraction is another version of the cultures but tourists still got the same experiences.

\subsection{Cultures Modification at Puri Anyar Kerambitan}

The first interviewed was conducted to the king of Puri Anyar Kerambitan, the first person in Bali that create a royal tourism. When the first time he created the tourism in his palace he knew that it is not possible to sell their original cultures as a tourist attraction. That's why then he created a new culture that could be peformed to tourists and brought alive some cultures that was already vanished in the local community and modified it as tourist attraction. Beside that, he created a new version of original cultures they have at Puri Anyar Kerambitan. The king has faith that the modification he did will not loosing the authencity of the original cultures because the original cultures still keep remain in heart of the palace. What their perform to tourists are a different thing. So today, there are two versions of cultures at the palace. The original one and the modified one.

The modified ones are the cultures without ritual and religious elements, and it is performed in the royal yard. The original or authentic ones are only for the royal's family. 


\subsection{Perception on Authenticity}

The interview that was conducted to scholars and expert, they were agree that most of cultures that was modified as tourist attraction lost their authenticity and it happened to all of cultural tourism destinations. According to them, there are some factors that lead to the loss of the authenticity, that factors are: (a) added something new to the culture, (b) the use of modern technologies, (c) use the language other than the mother language, (d) the reduction of time, (e) some cultures are only perfomed at a certain time, like in a full moon or a good day according to local people but now it's change. They cut the duration of time and perform at any time. But they also realize that cultures can be change or vanish like happened to some cultures in Bali where some locals left it because it's not appropriate anymore to todays life. They are really appreciate the Puri Anyar Kerambitan which is still preserve the original cultures they have and created the other version that is not contradictory with the custom and religion.

The tour operator that bring tourists to Puri Anyar Kerambitan consider that the commodification of royal cultures doesn't mean anything along as their customers consider the cultures they see is performe the balinese culture that they never seen before. Until now, there is no complaint about the cultures performance they see. Their customers always consider what they see is authentic.

From the tourists point of view who came to Puri Anyar Kerambitan said that the cultures performance are authentic and $100 \%$ of them said that they are authentic. The reason they said it was authentic is the performance they saw is only found at Puri Anyar Kerambitan even in Bali. The commodification did to royal cultures don't effect their perception about the authenticity of the cultures that was performed. The experiences they got is the main thing, what they see and what they feel that determine their appraisal to the cultures authenticity. They never distinguished that the cultures is original or already modified. They realize that cultures are dynamic form that always change through the centuries. As long as it is keep maintain the root the cultures it will stay authentic.

\section{Conclusion}

Puri Anyar Kerambitan develop a new model of commodification which could maintain the cultures authenticity of the royal palace. The Puri is keep maintain the original version for their own purpose and created modification version for tourism purpose. Those two version can walk side by side and everyone feel the authentic experience from their own point of view. Base on what the Puri Anyar Kerambitan did and from the perception of tourists, tour operators and cultural experts. The royal tourism at Puri Anyar Kerambitan create a new form of theory related to cultural authenticity. The theories are:

\section{1) Conceptual Authenticity}

The authenticity where the culture is still remain authentic and keep maintain the original tradition without change the form, function and procession the culture.

2) Contextual Authenticity 


\section{Macrothink

The perception of authenticity that come from the tourist who judge the authenticity only from the cover not of the cultures they see.

From the commodification point of view, the conceptualization of culture commodification at Puri Anyar Kerambitan can be classified into:

Apparent Commodification

1) The commodification that adopt the original knowledge with reduce some element that is related to rituality and religion.

2) Actual Commodification

The commodification that combined two or more cultures or added something new the original cultures. The combination was done to the cultures which never used or already vanished from the community.

3) New Commodification

The culture that is totally new created base on the creative idea of the royal family and declared as the royal creation.

\section{References}

Alvesson, M., \& Skoldberg, K. (2000). Reflexive Methodology: New Vistas for Quyalitative Research. London: Sage.

Ashworth. G. J. (1994). From History to Heritage - From Heritage to Identity. In G. J. Asworth \& P. J. Larkham (Eds.), Building a New Heritage. Tourism, Culture and Identity in the New Europe (pp.13-30). Londin: Routledge.

Baudrillard, J. (1983). Simulations. New York: Semiotext.

Belk, R. (1995). Studies in The New Consumer Behaviour. In D. Miller (Ed), Acknowledging Coonsumption: A review of New Studies. London: Routledge.

Berger, P. (1973). Sincerity and Authenticity in Modern Society in Public Interest. Spring: 81-90.

Boorstin, D. (1964). The Image: A Guide to Pseudo Events in American Society. New York: Harper.

Bruner, E. (1994). Abraham Lincoln as Authentic Reproduction: A Critique of Postmodernism. American Anthropologist, 397-415. http://dx.doi.org/10.1525/aa.1994.96.2.02a00070

Cinquin, C. (1987). Homo Coca Colens. In J. Umiker-Seebeok (Ed.), Marketing and Semiotic. Berlin, New York, Mouton de Gruyter.

Cohen, E. (1988). Authenticity and Commoditization in Tourism. Annals of Tourism Research, 15(3), 371-386. http://dx.doi.org/10.1016/0160-7383(88)90028-X

Cohen, E. (1988a). Traditions in the Qualitative Sociology of Tourism. Annals of Tourism Research, 15, 29-46. http://dx.doi.org/10.1016/0160-7383(88)90069-2

Cornet, J. (1975). African Art and Authenticity. African Arst, 9(1), 52-55. http://dx.doi.org/10.2307/3334983

Crang, D. (1996). Living History: Magic Kingdoms or a Quixotic Quest for Authenticity? Annals of Tourism Research, 23, 415-431. http://dx.doi.org/10.1016/0160-7383(95)00070-4 
Fawcett, C., \& Cormack, P. (2001). Guarding Authenticity at Literary Tourism Sites. Annals of Tourism Research, 28, 686-704. http://dx.doi.org/10.1016/S0160-7383(00)00062-1

Fitchett, J. A. (1997). Consumption and Cultural Commodification: The Case of The Museum as Commodity. University of Stirling. London.

Getz, D. (1994). Event Tourism and The Authenticity Dilemma. In W. Theobald (Ed.), Global Tourism (pp. 313-329). London: Butterworth-Heineman.

Girard, L. (2008). 'Cultural tourism: from culture fruition to culture communication and production', International Journal of Services Technology and Management, 10(1), 15-28. http://dx.doi.org/10.1504/IJSTM.2008.020343

Goffman, E. (1963). Behavior in Public Places: Notes on the Social Organization of Gatherings. New York: Free Press.

Govers, R., \& Go, F. M. (2004). Cultural identities constructed, imagined and experienced: a 3-gap tourist destination image model. Tourism Interdisciplinary Journal, 52(2), 165-182.

Greenwood, D. J. (1989). Culture by the pound: an anthropological perspective on tourism as cultural commoditization. In V. Smith (Ed.), Hosts and Guests: The Anthropology of Tourism, (2nd ed., pp.171-185), University of Pennsylvania Press, Philadelphia. http://dx.doi.org/10.9783/9780812208016.169

Halewood, C., \& Hannam, K. (2001). Viking Heritage Tourism: Authenticity and Commodification. Annals of Tourism Research, 28, 565-580. http://dx.doi.org/10.1016/S0160-7383(00)00076-1

Hirschman, E., \& Holbrook, M. (1982). Hedonic Consumption: Emerging Concepts, Methods and Propositions. Journal of Marketing, 46, 92-100. http://dx.doi.org/10.2307/1251707

Hughes, G. (1995). Authenticity in Tourism. Annals of Tourism Research, 22, 781-803. http://dx.doi.org/10.1016/0160-7383(95)00020-X

MacCannell, D. (1973). Staged Authenticity: Arrangements Social Space in Tourist Settings. American Journal of Sociology, 79, 589-603. http://dx.doi.org/10.1086/225585

Kopytoff, I. (1986). The cultural biography of things: Commoditization as process. In A. Appadurai (Ed.),. The Social Life of Things: Commodities in Cultural Perspective, Cambridge MA, University of Cambridge Press. http://dx.doi.org/10.1017/cbo9780511819582.004

MacCannell, D. (1976). The Tourist: A New Theory of the Leisure Class. London: MacMillan.

Redfoot, D. L. (1984). Touristic Authenticity, Touristic Angst, and Modern Reality. Qualitative Sociology, 7(4), 291-309. http://dx.doi.org/10.1007/BF00987097

Reisinger, Y., \& Steiner, C. (2006). Reconceptualizing object authenticity. Annals of Tourism Research, 33(1), 65-86. http://dx.doi.org/10.1016/j.annals.2005.04.003

Ritzer, G. (1993). The McDonaldization Thesis: An Investigation into the Changing Character of Contemporary Social Life. London: Sage.

Selwyn, T. (1996). Introduction. In T. Selwyn (Ed.), The Tourist Image, Myths and Myth Making in Tourism (pp. 1-32). Chichester: John Wiley and Sons. 
Sharpley, R. (1994). Tourism, Tourist and Society. London: Elm.

Trilling, L. (1972). Sincerity and Authenticity. London: Oxford University Press.

Tunbridge, J. E., \& Ashworth, G. J. (1996). Dissonant Heritage. The Management of The Past as a Resource in Conflict. Chichester: John Wiley and Son.

\section{Copyright Disclaimer}

Copyright reserved by the author(s).

This article is an open-access article distributed under the terms and conditions of the Creative Commons Attribution license (http://creativecommons.org/licenses/by/3.0/). 